\title{
Pengaruh Bimbingan Kelompok Teknik Written terhadap Kecerdasan Naturalis Siswa
}

\author{
Nadia Wahyuni Thalib, Maryam Rahim, Irvan Usman \\ 1,2,3 Bimbingan dan Konseling Fakultas Ilmu Pendidikan \\ Universitas Negeri Gorontalo
}

Email: nadiawahyuni@gmail.co.id

\begin{abstract}
ABSTRAK
Kenyataannya, sebagian besar siswa, khususnya, mereka yang duduk di sekolah dasar belum memiliki kesadaran akan pentingnya pelestarian alam. Ini merupakan indikasi kecerdasan naturalis yang rendah dari siswa sekolah dasar. Sebagai upaya mengatasi masalah tersebut, dibutuhkan suatu solusi, yaitu bimbingan kelompok teknik tertulis. Permasalahan dalam penelitian ini adalah apakah bimbingan kelompok teknik tertulis berpengaruh terhadap kecerdasan naturalis siswa sekolah dasar. Penelitian ini menggunakan metode pra-eksperimen dengan desain satu kelompok pretest dan posttest. Sampel penelitian adalah 15 orang. Pengumpulan data menggunakan kuesioner sebagai teknik utama. Data dianalisis dengan menggunakan uji-t. Berdasarkan temuan penelitian, disimpulkan bahwa ada pengaruh bimbingan kelompok teknik tertulis terhadap kecerdasan naturalis siswa kelas V SDN No. 85 Kota Tengah Kota Gorontalo. Kesimpulan ini diperoleh dari hasil analisis data, yang menunjukkan nilai thitung $=-20,598$, dan pada taraf signifikansi $0,05(14)$, diperoleh $\mathrm{t}$-tabel $=2,98$, yang berarti $\mathrm{t}$-count telah berada di luar area penerimaan H0. Ini berarti bahwa hipotesis yang mengatakan, "ada pengaruh bimbingan kelompok teknik tertulis terhadap kecerdasan naturalis siswa di kelas V SDN 85 Kota Tengah Kota Gorontalo, dapat diterima. Dengan kata lain, bimbingan kelompok teknik tertulis dapat meningkatkan kecerdasan naturalis siswa di kelas V SDN No.85 Kota Tengah Kota Gorontalo. Berdasarkan temuan penelitian, disarankan bahwa guru bimbingan dan konseling harus menerapkan bimbingan kelompok teknik tertulis sebagai upaya untuk meningkatkan kecerdasan naturalis siswa sekolah dasar.
\end{abstract}

Kata Kunci: Written; Kecerdasan; Naturalis; Siswa

\begin{abstract}
As a reality, the vast majority of students, in particular, those at elementary school have yet to have awareness of the importance of nature preservation. This constitutes an indication of low naturalist intelligence of elementary school students. As an effort to cope with the problem, it requires a solution, namely written technique group guidance. The problem of this research is whether or not written technique group guidance has an influence towards naturalist intelligence of elementary school students. The research uses a pre-experiment method with one group pretest and posttest design. The research samples are 15 people. The data collection uses a questionnaire as the main technique. The data are analyzed by using t-test. Based on the research finding, it concludes that there is an influence of written technique group guidance towards naturalist intelligence of students at grade V of SDN No. 85 Kota Tengah of Gorontalo City. This conclusion is obtained from the result of data analysis, which indicates the value of $t$-count $=-20,598$, and at a significance level of 0,05 (14), it obtains $t$-table $=2,98$, which meant the t-count has been outside of acceptance area of HO. This means that the hypothesis which says,
\end{abstract}

$\underline{\text { Pedagogika.fip@ung.ac.id }} \quad$ P-ISSN : 2086-4469 E-ISSN : 2716-0580 
PEDAGOGIKA

Volume 11 (Nomor 1) 2020

Hal. 12-25

"there is the influence of written technique group guidance towards naturalist intelligence of students at grade V of SDN 85 Kota Tengah of Gorontalo City, can be accepted. In other words, the written technique group guidance can increase the naturalist intelligence of students at grade V of SDN No.85 Kota Tengah of Gorontalo City. Based on the research finding, it is suggested that the guidance and counselling teachers should apply written technique group guidance as an effort to improve the naturalist intelligence of elementary school students.

Keywords: Written; Naturalist; Intelligence; Students.

(C) 2020 Nadia Wahyuni Thalib, Maryam Rahim, Irvan Usman Under The License CC-BY SA 4.0

\section{PENDAHULUAN}

Setiap manusia memiliki berbagai potensi kecerdasan. Hal ini sejalan dengan hasil penelitian Howard Gardner (dalam Suryadi, 2006: 34) yang menjelaskan bahwa semua manusia memiliki kecerdasan, tidak ada istilah manusia yang tidak cerdas. Tetapi kebanyakan di antara manusia memiliki persepsi bahwa seseorang yang cerdas identik dengan kepandaian dalam memenuhi tuntutan yang bersifat akademis, sehingga ia akan mampu menjalani kehidupan yang sukses. Persepsi ini memang sangat umum dijumpai dalam kehidupan masyarakat, tampaknya hal ini tidak hanya terjadi pada orang tua, sebab di kalangan guru di dunia pendidikan pun tampaknya sangat menghargai pencapaian prestasi siswanya di bidang akademik.

Pada umumnya masyarakat hanya memandang konsep cerdas dari bidang akademik saja, padahal mungkin saja seorang siswa tidak pintar di sekolah, namun cerdas dalam bidang menggambar, atau cerdas dalam berolahraga ataupun dapat memainkan musik dengan indah maupun melantunkan nyanyian dengan sangat merdu. Sehubungan dengan hal ini, Gardner (dalam Yusuf \& Nurihsan, 2011) menentang kepercayaan umum bahwa kecerdasan hanya berkaitan dengan kemampuan yang berkaitan dengan bidang akademis saja. Gardner (dalam Yusuf \& Nurihsan, 2011:) mengemukakan bahwa "Semua manusia memiliki delapan dasar inteligensi, yaitu inteligensi linguistik, inteligensi logika matematika, inteligensi visual ruang, inteligensi kinestetika tubuh, inteligensi musikal, inteligensi interpersonal, inteligensi intra personal, dan inteligensi natural. Kedelapan inteligensi ini disebut Multiple Intelligence (kecerdasan majemuk)". Salah satu kecerdasan itu adalah kecerdasan naturalis.

Menurut (Yusuf dan Nurihsan, 2011) "Kecerdasan naturalis merupakan kemampuan mengenali dan 


\section{PEDAGOGIKA}

Volume 11 (Nomor 1) 2020

\section{Hal. 12-25}

mengkategorisasikan spesies (flora dan fauna) di lingkungan sekitar, atau kepekaan pada fenomena alam lainnya (seperti awan dan gunung-gunung)". Kecerdasan naturalis merupakan salah satu kecerdasan yang berpotensi untuk pembentukan karakter siswa dalam berinteraksi dengan alam dan lingkungannya. Sejak usia dini, berbagai macam potensi perlu dilatihkan. Hal ini berguna untuk perkembangan diri sepanjang hidupnya. Pemberian pemahaman tentang pentingnya melestarikan lingkungan sekitar melalui pengembangan kecerdasan naturalis sejak dini diharapkan dapat mencegah siswa melakukan perilaku merusak, seperti mengeksploitasi lingkungan hidup yang ada di sekitar yang berakibat terjadinya bencana alam.

\section{Kecerdasan Naturalis Majemuk}

Kecerdasan di berbagai bidang yang dimiliki oleh setiap orang, disebut Gardner sebagai kecerdasan majemuk (multiple intelligence). Menurut Gardner (dalam Suryadi, 2006:35), kecerdasan seseorang meliputi delapan unsur kecerdasan, yakni kecerdasan matematika logika, kecerdasan bahasa, kecerdasan musical, kecerdasan visual spasial, kecerdasan kinestetis, kecerdasan interpersonal, kecerdasan intrapersonal, dan kecerdasan naturalis.
Selanjutnya Howard Gardner, menambahkan kecerdasan, yakni kecerdasan eksistensial, sehingga menjadi sembilan jenis kecerdasan (Ayriza, 2011; Samsudin; Haniza; dan Abdul Talib, 2015). Secara rinci masing-masing kecerdasan tersebut dijelaskan sebagai berikut:

\section{a. Kecerdasan logis matematis}

Kecerdasan logis matematis memuat kemampuan seseorang dalam berpikir secara induktif dan deduktif, berpikir menurut logika, memahami dan menganalisis pola angka-angka, serta memecahkan masalah dengan menggunakan kemampuan berpikir. Anak dengan kecerdasan logis matematis tinggi cenderung menyenangi kegiatan menganalisis dan mempelajari sebab akibat terjadinya sesuatu.

b. Kecerdasan bahasa

Kecerdasan bahasa memuat kemampuan seseorang untuk menggunakan bahasa dan kata-kata, baik secara tertulis maupun lisan, dalam berbagai bentuk yang berbeda untuk mengekspresikan gagasangagasannya. Anak dengan kecerdasan bahasa yang tinggi umumnya ditandai dengan kesenangannya pada kegiatan yang berkaitan dengan penggunaan suatu bahasa seperti membaca, menulis karangan, membuat puisi, menyusun kata-kata mutiara, dan sebagainya. 


\section{PEDAGOGIKA}

Volume 11 (Nomor 1) 2020

Hal. 12-25

c. Kecerdasan musikal

Kecerdasan musikal memuat kemampuan seseorang untuk peka terhadap suara-suara non verbal yang berada di sekelilingnya, termasuk dalam hal ini adalah nada dan irama. Anak dengan jenis ini cenderung senang sekali mendengarkan nada dan irama yang indah, entah melalui senandung yang di lagukannya sendiri, mendengarkan radio, tape recorder, pertunjukkan orkestra, atau alat musik yang dimainkannya sendiri.

d. Kecerdasan visual-spasial

Kecerdasan visual-spasial memuat kemampuan seseorang untuk memahami secara lebih mendalam hubungan antara objek dan ruang. Anak dengan kecerdasan ini memiliki kemampuan, misalnya untuk menciptakan imajinasi bentuk dalam pikirannya atau kemampuan untuk menciptakan bentuk-bentuk tiga dimensi seperti dijumpai pada orang dewasa yang menjadi pemahat patung atau arsitek suatu bangunan. Kemampuan membayangkan suatu bentuk nyata dan kemudian memecahkan berbagai masalah sehubungan dengan kemampuan ini adalah hal yang menonjol pada jenis kecerdasan visualspasial. e. Kecerdasan kinestetis

Kecerdasan kinestetis memuat kemampuan seseorang untuk secara aktif menggunakan bagian-bagian atau seluruh tubuhnya untuk berkomunikasi dan memecahkan berbagai masalah. Hal ini dapat dijumpai pada anak yang unggul pada salah satu cabang olahraga, seperti bulu tangkis, sepak bola, tenis, renang, dan sebagainya, atau bisa pula tampil pada anak yang pandai menari, terampil bermain akrobat, atau unggul dalam bermain sulap.

f. Kecerdasan interpersonal

Kecerdasan interpersonal menunjukkan kemampuan seseorang untuk peka terhadap perasaan orang lain. Mereka cenderung untuk memahami dan berinteraksi dengan orang lain sehingga mudah bersosialisasi dengan lingkungan di sekelilingnya. Kecerdasan semacam ini juga sering disebut sebagai kecerdasan sosial, yang selain kemampuan menjalin persahabatan yang akrab dengan teman, juga mencakup kemampuan seperti memimpin, mengorganisasi, menangani perselisihan antar teman, memperoleh simpati dari anak yang lain, dan sebagainya.

g. Kecerdasan intrapersonal

Kecerdasan intrapersonal

menunjukkan kemampuan seseorang untuk 
PEDAGOGIKA

Volume 11 (Nomor 1) 2020

Hal. 12-25

peka terhadap perasaan dirinya sendiri. Ia cenderung mampu untuk mengenali berbagai kekuatan maupun kelemahan yang ada pada dirinya sendiri. Anak semacam ini senang melakukan intropeksi diri, mengoreksi kekurangan maupun kelemahannya, kemudian mencoba untuk memperbaiki diri. Beberapa di antaranya cenderung menyukai kesunyian dan kesendirian, merenung, dan berdialog dengan dirinya sendiri.

h. Kecerdasan naturalis

Kecerdasan naturalis ialah kemampuan seseorang untuk peka terhadap lingkungan alam, misalnya senang berada di lingkungan alam yang terbuka, seperti pantai, gunung, cagar alam, atau hutan. Anak dengan kecerdasan seperti ini cenderung suka mengobservasi lingkungan alam seperti aneka macam bebatuan, jenis-jenis lapisan tanah, aneka macam flora dan fauna, bendabenda angkasa, dan sebagainya.

g. Kecerdasan eksistensial

Kecerdasan Eksistensial adalah kemampuan seseorang untuk menjawab persoalan- persoalan terdalam eksistensi atau keberadaan manusia. Kecerdasan ini sangat berpengaruh atas sebuah penghormatan. Kehormatan, kewibawaan dan penghargaan atas seseorang sangat ditentukan oleh seberapa besar orang tersebut menghargai orang lain. Semakin orang menghargai dan menganggap keberadaan seseuatu, maka sebesar itu pula orang dan lingkungan sekitar akan menghargai atas keberdaanya. Seseorang yang mempunyai kecerdasan eksistensi yang tinggi dia akan mampu menempatkan dirinya pada posisi di mana orang dan lingkungan sekitar senantiasa menghargai dan menganggap keberadaanya.

Berdasarkan uraian sebelumnya dapat disimpulkan bahwa kecerdasan naturalis adalah kemampuan dalam melakukan kategorisasi dan membuat hirarki terhadap keadaan organisme seperti tumbuhtumbuhan, binatang, dan alam. Salah satu ciri yang ada pada anak-anak yang kuat dalam kecerdasan naturalis adalah kesenangan mereka pada alam, binatang, misalnya berani mendekati, memegang, mengelus, bahkan memiliki naluri untuk memelihara. Gardner (Gangadevi dan Ravi, 2014) mengartikan naturalistic intelligence: It is the ability to understand nature and use the gifts of nature for one's own development. Students with high level of naturalistic intelligence do well as agriculturists, farmers, landscapers, etc. It is possible in an educational institution to develop the above eight types of intelligences. Connel (dalam Yaumi, 2012) mendeskripsikan bahwa "orang yang 
PEDAGOGIKA

Volume 11 (Nomor 1) 2020

Hal. 12-25

naturalistik dapat digambarkan sebagai orang yang: (1) memiliki minat yang dalam terhadap lingkungan, (2) melibatkan diri dalam alam, (3) memelihara alam dari polusi, (4) melakukan navigasi alam dengan mudah, (5) mampu melihat pola-pola dalam alam dengan mudah, (6) mengenal berbagai jenis berbatuan, flora dan fauna, bahkan berbagai jenis burung yang hidup di alam tersebut, (7) membawa alam ke dalam ruang kelas jika sebagai seorang guru".

Carvin (dalam Yaumi, 2012) mendefinisikan bahwa "Kecerdasan naturalis adalah kemampuan seseorang untuk mengidentifikasi dan mengklasifikasikasi pola-pola alam (nature)". Di samping itu Bowles (dalam Yaumi 2012) menyatakan bahwa "Komponen inti kecerdasan naturalis adalah kepekaan terhadap alam (flora, fauna, formasi awan, gunung-gunung), keahlian dalam membedakan anggota-anggota suatu spesies, mengenali eksistensi spesies lain, dan memetakan hubungan antara beberapa spesies baik secara formal maupun informal. Memelihara alam dan bahkan menjadi bagian dari alam itu sendiri seperti mengunjungi tempat-tempat yang banyak dihuni binatang, dan mampu mengetahui hubungan antara lingkungan dan alam merupakan suatu kecerdasan yang tinggi mengingat tidak semua orang dapat melakukan dengan mudah".

Menurut (Suryadi, 2006) "kecerdasan naturalis adalah keahlian mengenal dan mengeksplorasikan spesies (flora dan fauna) di lingkungan sekitar, mengenal eksistensi spesies, memetakan hubungan antara beberapa spesies. Suryadi juga menjelaskan bahwa kecerdasan ini juga meliputi kepekaan pada fenomena antara beberapa spesies dan kepekaan pada fenomena alam lainnya". Dari pendapat para ahli dapat disimpulkan bahwa kecerdasan naturalis adalah kecerdasan yang berkaitan dengan kemampuan seseorang untuk peka terhadap lingkungan serta mampu mengenali dan mengkategorisasi spesies (flora dan fauna).

Orang yang memiliki kecerdasan naturalis dapat dilihat dari perilaku yang ditunjukkannya dalam kehidupan sehari-hari. Ada beberapa ciri atau karakteristik orang yang memiliki kecerdasan naturalis. (Suryadi, 2006) mengemukakan ciri-ciri anak yang memiliki kecerdasan naturalis dapat dilihat dari cara ia menyayangi binatang, keinginan ia memiliki hewan peliharaan, kesukaan ia mengamati burung dan tumbuhan, dapat menikmati benda dan cerita yang berkaitan dengan fenomena alam, kesukaan mengamati apa yang terjadi di 
PEDAGOGIKA

Volume 11 (Nomor 1) 2020

Hal. 12-25

lingkungan dan lain sebagainya. Pendapat yang tidak jauh berbeda dikemukakan oleh (Yaumi, 2012), bahwa ciri orang yang memiliki kecerdasan naturalis adalah; (1) berbicara banyak tentang binatang, tumbuhtumbuhan atau keadaan alam, (2) senang berdarmawisata ke alam, kebun binatang, atau di museum, (3) memiliki kepekaan pada alam (seperti hujan, badai, petir, gunung, tanah, dan semacamnya, (4) senang menyiram bunga atau memelihara tumbuhtumbuhan dan binatang, (5) suka melihat kandang binatang, burung, atau akuarium, (6) senang ketika belajar ekologi, alam, binatang, dan tumbuh-tumbuhan, berbicara banyak tentang hak-hak binatang, dan cara kerja planet bumi, (8) senang melakukan proyek pelajaran yang berbasis alam (mengamati burung-burung, kupu-kupu atau serangga lainnya, tumbuh-tumbuhan dan memelihara binatang), (9) suka membawa ke sekolah binatang-binatang kecil, bunga, daun-daunan, kemudian membagi pengalaman dengan guru dan teman-teman lain, (10) mengerjakan dengan baik topiktopik yang melibatkan system kehidupan binatang, cara kerja alam, dan bahkan manusia.

Karakteristik anak yang memiliki keceradasan naturalis: (1) Feels at their best in the outdoors, (2) Strives for balance with nature and mind and body, (3) Demonstrates an empathy with nature and it's creatures, (4) Has a strong sense of responsibility towards the environment, (5) Possesses a sensitivity to animal abuse and environmental destruction, (6) Enjoys exploration, adventure, open-ended experiences, dan (7) Feels an affinity toward animals in general, pets in particular (Hoekstra, $\quad$ http://www.Internationalmontessori.org).

Dari beberapa pendapat para ahli dapat disimpulkan bahwa anak yang memiliki kecerdasan naturalis memiliki ciri-ciri di antaranya berbicara banyak tentang binatang, tumbuh-tumbuhan dan keadaan alam, memiliki kepekaan alam (seperti awan, hujan, dan badai), memiliki hewan peliharaan, menyayangi binatang, senang memelihara dan menyiram tumbuhtumbuhan, serta senang berdarmawisata ke alam, kebun binatang dan museum. Ciri-ciri kecerdasan naturalis yang digunakan dalam penelitian ini adalah ciri-ciri kecerdasan naturalis yang dikemukakan oleh (Yaumi, 2012).

\section{Bimbingan Kelompok Teknik Written}

Bimbingan kelompok merupakan salah satu strategi dalam pelayanan bimbingan dan 
PEDAGOGIKA

Volume 11 (Nomor 1) 2020

Hal. 12-25

konseling. Strategi dalam layanan bimbingan dan konseling meliputi bimbingan klasikal, bimbingan kelompok, konseling kelompok, dan konseling individual. Prayitno dan Amti (2013:310) menyebut "bimbingan kelompok sebagai salah satu jenis layanan bimbingan dan konseling." Prayitno dan Amti (2013:310) menjelaskan bahwa "layanan bimbingan kelompok merupakan layanan bimbingan yang diberikan dalam suasana kelompok dengan melakukan kegiatan dalam bentuk pemberian informasi untuk keperluan tertentu bagi para anggota kelompok".

Menurut (Rusmana, 2009) ada empat tahapan dalam bimbingan kelompok, yakni:

a. Tahap Awal

Tahap ini merupakan tahap pembentukan ataupun tahap pengenalan. Pada tahap ini konselor menyampaikan tujuan diselenggarakannya kegiatan layanan bimbingan kelompok, kompetensi yang ingin dicapai, serta materi dan skenario kegiatan. Selanjutnya konselor membentuk kelompok, pada umumnya dalam pembentukan kelompok ini para anggota kelompok saling memperkenalkan diri agar terlibat dan aktif dalam kelompok. Setelah itu, konselor memberikan kesempatan kepada anggota kelompok untuk melakukan konsolidasi atau tugas-tugas dalam pelaksanaan bimbingan kelompok.

b. Tahap Transisi

Pada tahap kedua ini konselor melakukan penanganan konflik-konflik internal yang disebabkan oleh keengganan konseli dalam melaksanakan aktivitas kelompok, kemudian konselor melakukan pembagian tugas dan kontrak.

c. Tahap Kerja

Tahap ini merupakan inti dari kegiatan bimbingan kelompok, adapun kegiatan yang dilakukan pada tahap ini adalah sebagai berikut: (1) eksperientasi, (2) identifikasi, (3) analisis, dan (4) generalisasi.

d. Tahap Terminasi

Tahap terminasi atau tahap pengakhiran adalah tahap yang terakhir dalam bimbingan kelompok. Adapun kegiatan yang dilakukan pada tahap ini yaitu: (1) refleksi umum: tahap di mana konselor mengajak konseli untuk melakukan review atas proses konseling yang telah dilakukan, dan (2) tindak lanjut

Written (menulis) merupakan aktivitas yang bisa digolongkan ke dalam aktivitas akademik yang membutuhkan kemampuan berpikir. Hal itu sejalan dengan pendapat Imran Rosidi (dalam Widodo, 2013) yang mengatakan "menulis merupakan 
PEDAGOGIKA

Volume 11 (Nomor 1) 2020

\section{Hal. 12-25}

kegiatan menuangkan pikiran, gagasan dan perasaan seseorang yang diungkapkan dalam bahasa tulisan".

Terdapat beberapa teknik written (menulis), yang dapat dipilih dalam pelaksanaan layanan bimbingan dan konseling. (Rusmana,2009) memperkenalkan beberapa macam jenis written, yaitu: melengkapi kalimat (sentences-completions exercise), mengisi daftar isian (listing exercise), menulis respon (written-response exercise), buku harian (diaries), serta puisi (poetry). Teknik menulis (written)yang digunakan dalam penelitian ini adalah menulis puisi. Puisi merupakan hasil pikiran seseorang yang ditulis dengan menggunakan bahasa yang imajinatif atau menggunakan bahasa kias. Tulisan tersebut kemudian dipersingkat dan diberi rima dengan bunyi yang padu. Hal ini bertujuan untuk menambah nilai keindahan dari puisi.

Hasil pengamatan yang dilakukan pada siswa kelas V SDN Nomor 85 Kota Tengah, dan wawancara dengan guru di sekolah tersebut, masih terdapat kurang lebih 30 orang siswa yang sering membuang sampah di sembarangan tempat, merusak tanaman-tanaman yang tumbuh di sekitar mereka, serta sering merusak lingkungan sekitar seperti mencorat-coret pohon, tembok dan fasilitas umum lainnya. Solusi terhadap masalah rendahnya kecerdasan naturalis di kalangan siswa ini dilakukan melalui layanan bimbingan kelompok teknik written.

Melalui teknik written siswa dapat melakukan berbagai aktivitas, seperti menulis pertanyaan, menuliskan reaksinya terhadap suatu peristiwa, serta aktivitas yang dapat menghasilkan ide-ide yang mereka tuangkan dalam bentuk cerita dan puisi. Teknik written yang digunakan dalam penelitian ini dibatasi pada kegiatan menulis puisi. Menulis puisi dapat memungkinkan siswa untuk menuangkan ide-ide berupa kata imajinatif berdasarkan hasil pemikiran dan pengalaman yang mereka miliki. Pengalaman tersebut mereka tuangkan dalam bentuk puisi sesuai dengan tema yang telah ditentukan yang berhubungan dengan alam dan makhluk hidup seperti gunung, laut, sungai, tumbuhtumbuhan, dan hewan. Hal ini bertujuan untuk membantu siswa mendapatkan pemahaman tentang alam dan pentingnya memelihara kelestarian alam, dalam arti mengembangkan kecerdasan naturalis.

Permasalahan penelitian ini adalah: apakah terdapat pengaruh bimbingan kelompok teknik written terhadap kecerdasan naturalis siswa sekolah dasar nomor 85 kecamatan kota tengah kota Gorontalo? 
PEDAGOGIKA

Volume 11 (Nomor 1) 2020

Hal. 12-25

Dengan demikian maka penelitian ini dilakukan dengan tujuan mengetahui pengaruh bimbingan kelompok teknik written terhadap kecerdasan naturalis siswa sekolah dasar nomor 85 kecamatan kota tengah kota Gorontalo.

\section{METODE PENELITIAN}

Penelitian ini menggunakan one group pre-test and post-test design. Anggota populasi dalam penelitian ini adalah seluruh siswa kelas V SDN Nomor 85 Kota Tengah dengan jumlah siswa 50 orang. Anggota sampel sebanyak 15 orang (menggunakan batas minimal anggota sampel untuk penelitian eksperimen). Data dikumpulkan dengan menggunakan angket. Teknik analisis data yang digunakan adalah uji-t (Sudjana, 2005).

\section{HASIL PENELITIAN DAN PEMBAHASAN}

Berdasarkan hasil analisis data terdapat perubahan yang signifikan pada kecerdasan naturalis siswa kelas V SDN NO. 85 Kota Tengah Kota Gorontalo setelah pemberian tretment layanan bimbingan kelompok teknik written. Hal tersebut dapat dilihat dari jumlah skor hasil pre-test sebesar 1644. Setelah memberikan delapan kali perlakuan (treatment) berupa bimbingan kelompok teknik menulis (written), dalam hal ini menulis puisi dengan topik yang berbeda-beda sesuai dengan indikator dari kecerdasan naturalis, maka skor hasil posttest berjumlah 1962. Hal ini berarti bahwa setelah diberikan perlakuan (treatment) berupa layanan bimbingan kelompok teknik written terhadap maka kecerdasan naturalis siswa mengalami peningkatan.

Berdasarkan hasil analisis data diperoleh $t_{\text {hitung }}=-20,598$. Pada taraf nyata 0,05 (14) diperoleh $t_{\text {tabel }}=2,98$, artinya $t_{\text {hitung }}$ berada di luar daerah penerimaan $\mathrm{H}_{0}$. Hal ini berarti bahwa hipotesis yang berbunyi "terdapat pengaruh bimbingan kelompok teknik written terhadap kecerdasan naturalis siswa kelas V SDN Nomor 85 Kota Tengah" dapat diterima. Dengan kata lain bimbingan kelompok teknik written dapat meningkatkan kecerdasan naturalis siswa kelas V Sekolah Dasar. Untuk jelasnya dapat dilihat pada kurva berikut: 


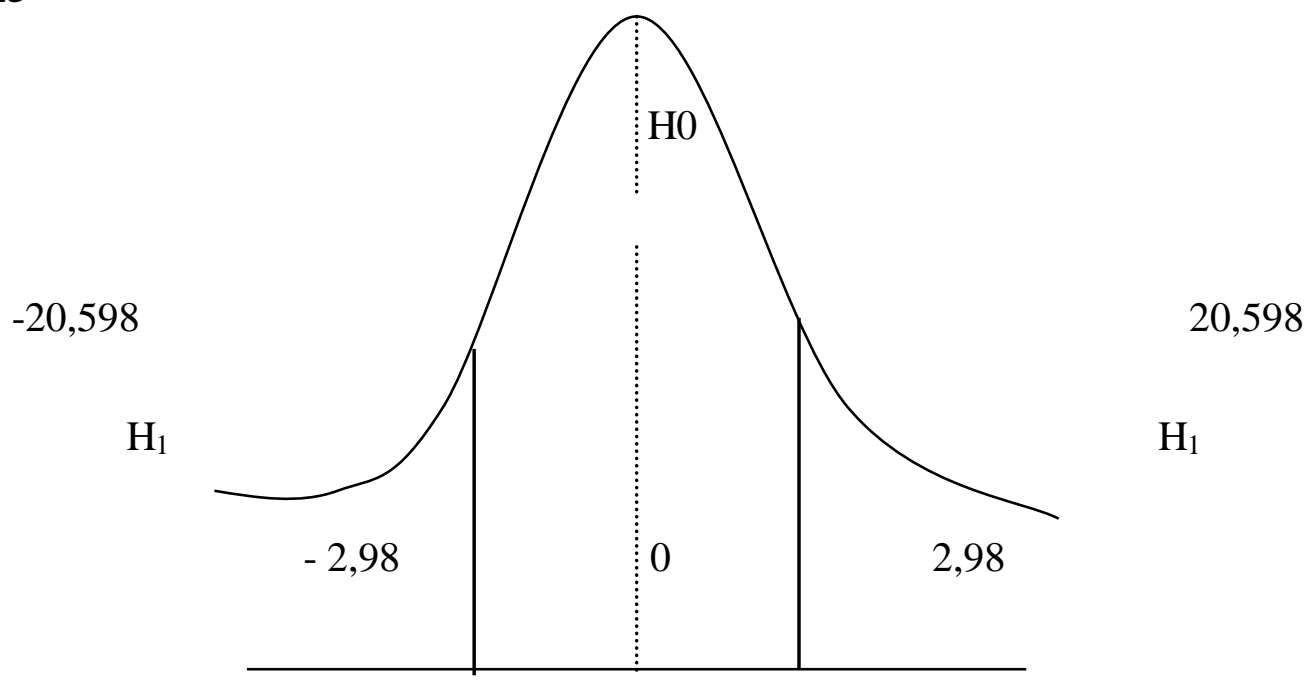

\section{Gambar 1. Kurva Penerimaan dan Penolakan Hipotesis $\left(\mathrm{X}_{1}\right.$ dan $\left.\mathrm{X}_{2}\right)$}

Masalah tentang alam dan makhluk hidup merupakan hal yang penting. Masalah ini jika tidak ditangani dengan serius maka akan menimbulkan kerusakan dan pemanasan global yang mengakibatkan bencana alam terjadi di mana-mana sehingga berdampak pada kerugian yang besar bagi seluruh alam semesta. Mengembangkan kecerdasan naturalis pada siswa sekolah dasar merupakan salah satu upaya untuk meminimalisir kerusakan alam yang diakibatkan oleh perilaku manusia. Bagi siswa kelas sekolah dasar, kecerdasan naturalis itu sangat penting untuk dikembangkan, karena dengan memiliki kecerdasan naturalis yang tinggi sejak dini anak akan berkembang menjadi seorang yang memiliki kesadaran betapa pentingnya memelihara dan merawat lingkungan sekitar, memiliki kepedulian terhadap alam sekitar, serta memanfaatkan alam secara efektif.

Membantu siswa menjadi peduli terhadap lingkungan sekitar membutuhkan usaha yang sungguh-sungguh serta kerja sama pihak-pihak sekolah, terutama guru bimbingan dan konseling. Bimbingan kelompok teknik menulis (written), dalam hal ini menulis puisi dapat digunakan oleh guru bimbingan dan konseling untuk mengembangkan kecerdasan naturalis siswa.

Menulis merupakan aktivitas menuangkan ide-ide, pikiran, pendapat, dan juga perasaan melalui bahasa tulisan atau secara tertulis. Aktivitas menulis memberikan kesempatan bagi penulis untuk memvisualisasikan hal-hal yang dipikirkan, diinginkan, dirasakan dalam bentuk bahasa tulis sehingga dapat diketahui oleh orang 
PEDAGOGIKA

Volume 11 (Nomor 1) 2020

Hal. 12-25

lain. Menulis juga dapat digunakan untuk mengungkapkan sebuah pengalaman tentang seseorang atau suatu sistuasi seakan-akan mereka yang mengalaminya. Menurut (Silberman, 2006) aktivitas menulis memungkinkan siswa untuk memikirkan pengalaman yang mereka miliki. Menulis merupakan sebuah cara dramatis untuk meningkatkan perenungan secara mandiri dan mengungkapkan secara tertulis.

Menulis puisi dengan tema yang berhubungan dengan alam memungkinkan siswa memikirkan, merenungkan dan mengungkapkan secara tertulis berbagai aktivitas yang dapat dilakukannya dalam mencintai dan memelihara alam, seperti mencintai dan memelihara binatang dan tanaman, melindungi alam dari kerusakan sebagai akibat perbuatan manusia, serta menggunakan kekayaan alam secara produktif tanpa merusak alam. Hasil tulisan mereka selanjutnya dibahas melalui bimbingan kelompok untuk mendapatkan respon dari sesama anggota kelompok, yang pada akhirnya semua anggota memiliki pemahaman dan kencitaan terhadap alam, serta komitmen untuk melestarikan alam.

Beberapa penelitian sejenis memperkuat/memperlemah hasil penelitian ini, antara lain menunjukkan bahwa kecerdasan naturalis pada anak-anak dapat dikembangkan melalui berbagai aktivitas. Hasil penelitian (Juniarti, 2015) menyimpulkan bahwa metode kunjungan lapangan dapat meningkatan kecerdasan naturalis anak kelompok B PAUD Terpadu Bintuhun Bengkulu. Demikian pula (Yasbita; Giyartini, dan Lutfiana, 2017) menyimpulkan hasil penelitiannya, bahwa kecerdasan naturalis anak Bambim Al-Abror Kecamatan Mangkubumi Kota Tasikmalaya dapat ditingkatkan melalui kegiatan bercocok tanam.

Berbeda dengan teknik yang digunakan dalam kedua penelitian tersebut, penelitian yang dilakukan ini menggunakan layanan bimbingan dan konseling, yakni bimbingan kelompok teknik menulis puisi (poetry written), yang telah menemukan hasil yang sama, yakni dapat meningkatkan kecerdasan naturalis pada anak usia sekolah dasar. Oleh sebab itu sekolah-sekolah hendaknya melakukan berbagai aktivitas pengembangan kecerdasan naturalis anak/siswa sebagai upaya mengembangkan kecintaan anak terhadap lingkungan, yang pada gilirannya dapat mencegah terjadinya kerusakan lingkungan alam.

Hasil penelitian ini menyimpulkan bahwa bimbingan kelompok dengan 
PEDAGOGIKA

Volume 11 (Nomor 1) 2020

Hal. 12-25

menggunakan teknik written (dalam penelitian ini dalam bentuk puisi) dapat memungkinkan siswa menuangkan ide-ide atau gagasan-gagasan terkait dengan kecintaan mereka terhadap lingkungan dan makhluk hidup yang ada di sekitar mereka yang dituangkan dalam bentuk tulisan. Dengan demikian rasa kepedulian dan kecintaan terhadap lingkungan dan makhluk hidup dapat ditanamkan pada diri siswa sejak dini agar nantinya mereka dapat mengaplikasikannya dengan sungguhsungguh di masa-masa selanjutnya.

\section{KESIMPULAN}

Berdasarkan hasil penelitian dapat disimpulkan bahwa bimbingan kelompok teknik written berpengaruh terhadap kecerdasan naturalis siswa kelas V SDN Nomor 85 Kota Tengah Kota Gorontalo, dengan kata lain bimbingan kelompok teknik written dapat meningkatkan kecerdasan naturalis siswa sekolah dasar. Dengan demikian disarankan, agar guru bimbingan dan konseling dapat menggunakan bimbingan kelompok teknik menulis (written) dalam upaya meningkatkan kecerdasan naturalis siswa sekolah dasar.

\section{REFERENSI}

Ayriza, Y. 2011. Cara Mnegstimulasi Kecerdasan naturalis serta

$\underline{\text { Pedagogika.fip@ung.ac.id } \quad P-I S S N ~: ~ 2086-4469 ~ E-I S S N ~: ~ 2716-0580 ~}$ 
PEDAGOGIKA

Volume 11 (Nomor 1) 2020

Hal. 12-25

(Metode, Teknik dan Aplikasi). Widodo, Joko. 2013. Peningkatan Bandung: Rizqi Press.

Samsudin, Ali Moh; Noor Hasyimah Haniza; dan Corrienna Abdul Talib. 2015. The Reationship between Multiple Intelligences with Preferred Science Teaching and Sience Process Skills. Journal of Education and Learning, Vol. 9 (1), pp. 53-59.

Silberman, L Melvin. 2006. Active Learning (101 Cara Belajar Siswa Aktif). Bandung: Nusamedia.

Sudjana. 2005. Metoda Statistika. Bandung: Tarsito.

Suryadi. 2006. Kiat Jitu Dalam Mendidik Anak (Berbagai Masalah Pendidikan \& Psikologi). Jakarta: Dani Jaya Abadi.

Uno, B Hamzah \& Masri Kudrat. 2014. Mengelola Kecerdasan Dalam Pembelajaran. Jakarta: Bumi Aksara. Kemampuan Menulis Puisi Melalui Penerapan Strategi Indentifikasi Berbasis Kecerdasan Majemuk Pada Siswa Kelas X-A SMA Negeri 1 Gemolong Tahun Ajaran 2011/2012. Tesis. Surakarta: Program Pascasarjana Universitas Sebelas Maret Surakarta.

Yasbiati; Rosalina Giyartini, Anisa Lutfiana. 2017. Upaya Meningkatkan Kecerdasan Naturalis Melalui Kegiatan Bercocok Tanam di Bambim AlAbror Kecamatan Mangkubumi Kota Tasikmalaya. Jurnal PAUD Agapedia, Vol. 1, No. 2, Desember 2017, page 203-213.

Yaumi, Muhammad. 2012. Pembelajaran Berbasis Multiple Intelligence. Jakarta: Dian Rakyat.

Yusuf, Syamsu \& Nurihsan, Achmad Juntika. 2011. Landasan Bimbingan dan Konseling. Bandung: Remaja Rosdakarya.

$\underline{\text { Pedagogika.fip@ung.ac.id } \quad P-I S S N ~: ~ 2086-4469 ~ E-I S S N ~: ~ 2716-0580 ~}$ 